\title{
PENINGKATAN KOMPETENSI GURU MELALUI PELATIHAN MICROSOFT POWER POINT DAN PELATIHAN INTERNET UNTUK MENGHADAPI KURIKULUM K-13 DI SMPN 20 PALEMBANG
}

\author{
Agustina Heryati ${ }^{1}$, Dhamayanti ${ }^{2)}$ \\ 1), 2)Program Studi Manajemen Informatika Universitas Indo Global Mandiri \\ Jalan Jenderal Sudirman No. 629 Palembang Kode pos 30129 \\ Email : agustina.heryati@uigm.ac.id ${ }^{1}$, dhamayanti@uigm.ac.id ${ }^{2)}$
}

\begin{abstract}
ABSTRAK
Guru merupakan salah satu unsur yang sangat penting dalam pengelolaan pendidikan dalam kegiatan proses ngajar mengajar di sekolah, oleh karena itu kompetensi guru harus di perhatikan dengan baik oleh pihak sekolah. Peningkatan kompetensi Guru harus di tingkatkan dalam menghadapi tantangan kurikulum K-13. Tantangan Kurikulum K-13 dalam hal kemajuan teknologi informasi yang semakin pesat dan maju sehingga menuntut Guru harus memiliki kompetensi di bidang komputer. Guru di wajibkan mahir dalam pengoperasian komputer baik, sehingga Guru membutuhkan pelatihan komputer sebagai tambahan. Pelatihan komputer dapat membatu Guru dalam segala bidang salah satunya dalam dunia pendidikan yakni dalam proses ngajar mengajar di Sekolah SMPN 20 Palembang. Salah satunya Pelatihan Microsoft Power Point dan Pelatihan Internet. Pelatihan ini bertujuan agar Guru dapat membuat pembelajaran yang menarik dan inovatif dapat juga memberikan tampilan yang bervariatif dalam penyampaian materi dalam proses pembelajaran dan memberikan banyak pengetahuan dan penambahan materi pembelajaran bagi Guru di sekolah. Kompetensi Guru semakin meningkat dalam proses pembelajaran memiliki dampakyang baik bagi Siswa/i di SMPN 20 Palembang juga dan memiliki daya jual yang baik bagi Guru tersebut. Peningkatan Kompetensi Guru melalui pelatihan Microsoft Power Point dan Pelatihan Internet di SMPN 20 Palembang diharapkan dapat memberikan masukan yang baik bagi sekolah dan dapat menambah kualitas dan kuantitas Guru di SMPN 20 Palembang dan dapat meningkatkan mutu pendidikan di Sekolah SMPN 20 Palembang.
\end{abstract}

Kata kunci : Kompetensi Guru, Microsoft Power Point, Internet, Kurikulum K-13

\section{PENDAHULUAN}

Pengabdian kepada Masyarakat (PkM) merupakan salah perwujudan dari Tri Dharma Perguruan Tinggi. Kegiatan PkM yang dilaksanakan untuk melatih Guru dalam mengahadapi kurikulum K-13. Guru merupakan salah satu pengelolah pendidikan dalam proses pembelajaran di sekolah, sehingga Guru merupakan salah satu unsur penting yang dapat meningkatkan mutu sekolah. Kualitas pendidikan yang baik sangat ditentukan oleh penilaian standar kualitas guru. Oleh karena itu, Guru perlu meningkatkan kompetensinya seperti tercantum dalam Undang-undang Nomor 14 Tahun 2005 tentang Guru dan Dosen. Kualitas guru yang baik perlu adanya peningkatan kompetensi Guru. Peningkatan Kompetensi Guru dalam penguasaan terhadap aspek pengetahuan, keterampilan, dan sikap kerja dalam suatu pekerjaan agar dapat menunjukkan kualitasnya sebagai Guru yang professional.

Peningkatan kompetensi Guru dapat melalui berbagai pelatihan yang di berikan oleh pihak sekolah. Pelatihan komputer merupakan salah satu pelatihan yang dapat membantu dalam menghadapi tantangan dari kurikulum K-13. Tantangan Kurikulum K-13 dalam hal kemajuan teknologi informasi yang semakin pesat dan maju sehingga menuntut Guru harus memiliki kompetensi di bidang komputer. Guru harus dapat mengatur manajemen agar terlaksananya kegiatan PkM yang lebih inovatif. (Heryati \& Afriyani, 2017)

Kurikulum K-13 menekankan pada pendidikan yang berkarakter, sehingga akan menjadi fondasi pada tahap berikutnya. Kurikulum K-13 merupakan kurikulum yang telah di tetapkan Pemerintah yang memiliki empat aspek penilaian, yaitu aspek pengetahuan, aspek keterampilan, aspek sikap, dan perilaku. Di dalam Kurikulum K-13, terutama di dalam materi pembelajaran terdapat materi yang dirampingkan dan materi yang ditambahkan. Pembelajaran kurikulum K-13 ditujukan untuk 
mengembangkan potensi Perserta Didik agar memiliki kemampuan hidup sebagai pribadi dan warga negara yang beriman, produktif, kreatif, inovatif, dan afektif, serta mampu berkontribusi pada kehidupan masyarakat, berbangsa, bernegara, dan berperadaban dunia. Dalam menghadapi tantangan K-13 Guru di wajibkan mahir dalam pengoperasian komputer baik, sehingga Guru membutuhkan pelatihan komputer sebagai tambahan. Pelatihan komputer dapat membantu Guru dalam segala bidang salah satunya dalam dunia pendidikan yakni dalam proses ngajar mengajar di Sekolah SMPN 20 Palembang.

SMPN 20 Palembang merupakan Sekolah Menengah Pertama Negeri yang ada di kota Palembang. SMPN 20 Palembang beralamat di Jl. Ki Anwar Mangku, Plaju Ulu, Kec. Plaju, Kota Palembang, Sumatera Selatan 30267. Peningkatan kompetensi Guru di SMPN 20 dengan diadakan pelatihan komputer yakni pelatihan Microsoft Power Point dan Pelatihan Internet. Pelatihan ini bertujuan untuk pengetahuan tambahan untuk menghadapi kurikulum K-13. Kompetensi Guru akan meningkat sehingga tujuan pembelajaran dapat dengan mudah diterapkan dan sesuai dengan apa yang di harapkan.

Pelatihan Microsoft Power Point ini akan melatih Guru dalam membuat tampilan pembelajaran lebih menarik, inovatif juga bervariatif dalam penyampaian materi. Materi ini dikembangkan melalui media interaktif materi dapat ditambahkan menjadi lebih interaktif dengan menggunakan Microsoft Office Power point di awali dengan Identifikasi tujuan pembelajaran, Analisis Pembelajaran, Butir-butir tes. Dalam peningkatan pemahaman untuk Guru akan pentingnya memiliki ketrampilan tambahan untuk mempresentasikan tugastugas yang dibebankan dari suatu program bagi Guru SMPN 20 Palembang. (Pratiwi, 2018)

Microsoft Office Power point merupakan salah satu program aplikasi perangkat lunak yang menyediakan tempat membuat slide pembelajaran untuk menampung pikiran pembicaraan yang akan disampaikan pada peserta didik. Dengan adanya fasilitas dari Microsoft power point yakni animasi, sehingga sebuah slide dapat diubah dengan menarik, agar menarik perhartian dari Peserta Didik. Penambahan pengetahuan juga didapat dari pengelolaan Internet sehingga Guru membutuhkan pelatihan Internet agar dapat memberikan masukan dan tambahan materi pembelajaran sehingga materi terus akan terus update.

Menurut (Suharmanto, 2017) internet merupakan kumpulan jaringan yang berskala global yang mana tidak ada satupun dari orang, kelompok atau organisasi yang bertanggung jawab untuk menjalankan internet. Dimana dengan adanya keterampilan mengelola Internet maka kita dapat mendapatkan informasi yang banyak dan penambahan pengetahuan.

Peningkatan Kompetensi Guru melalui pelatihan Microsoft Power Point dan Pelatihan Internet di SMPN 20 Palembang diharapkan dapat memberikan tambahan pengetahuan yang baik bagi sekolah dan dapat menambah kualitas dan kuantitas Guru di SMPN 20 Palembang dalam pengoperasian komputer sehingga tamatan Siswa/i SMPN 20 Palembang menjadi Siswa/i yang berprestasi dan terampil, karena di tunjang dengan adanya peningkatan kompetensi Guru juga dapat meningkatkan mutu pendidikan di Sekolah SMPN 20 Palembang.

\subsection{Tujuan PkM}

Tujuan kegiatan pengabdian kepada masyarakat yaitu:

1. Meningkatkan Kompetensi Guru SMPN 20 Palembang dalam menghadapi Kurikulum K-13;

2. Meningkatkan kemampuan dan keterampilan membuat tampilan pembelajaran yang menarik, inovatif, dan variatif bagi Guru SMPN 20 Palembang dengan melalui pelatihan Microsoft Power Point;

3. Menambah tambahan pengetahuan bagi Guru SMPN 20 Palembang dengan pelatihan Internet;

4. Pembaharuan materi bagi Guru SMPN 20 Palembang dengan pelatihan Internet;

5. Meningkatkan keterampilan di bidang komputer;

6. Meningkatkan Mutu Pendidikan di Sekolah SMPN 20 Palembang.

\subsection{Manfaat PkM}

Manfaat kegiatan Pengabdian kepada masyarakat yaitu:

1. Dapat Memberikan peningkatan kompetensi bagi Guru SMPN 20 Palembang;

2. Dapat Memberikan kemampuan dan keterampilan dalam mengelola Microsoft Power Point ;

3. Dapat Meningkatkan pengelolaan Internet;

4. Dapat memberikan tambahan pengetahuan dan penambahan materi pembelajaran bagi Guru SMPN 
20 Palembang;

5. Dapat meningkatkan keterampilan dalam pengoperasian komputer bagi Guru;

6. Dapat menerapkan kurikulum K-13 oleh pihak sekolah SMPN 20 Palembang;

7. Dapat menjadi guru propesional.

\section{METODE PELAKSANAAN PENGABDIAN}

\subsection{Tahapan Pelaksana Kegiatan PKM}

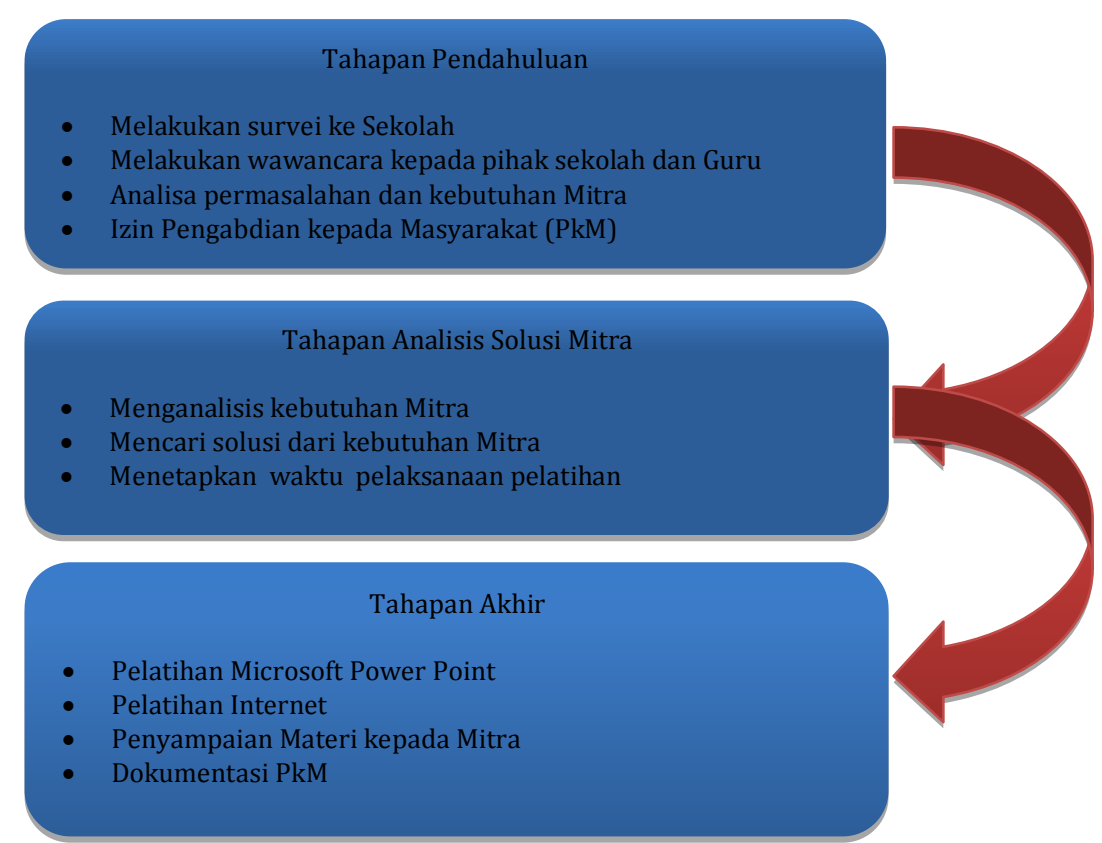

Gambar 1. Tahapan Pelaksana Kegiatan PkM

\subsection{Analisa dan Solusi Permasalahan Mitra}

Analisa solusi dan permasalahan Mitra melalui pendekatan sebelumnya yakni melalui survei dan wawancara dengan pihah Sekolah SMPN 20 Palembang maka didapatkan analisa permasalahan Guru dalam meningkatkan kompetensi Guru untuk menghadapi Kurikulum K-13 dengan diadakan pelatihan Komputer. Pelatihan komputer diharapkan Guru SMPN 20 Palembang lebih mahir dalam mengoperasikan komputer. Pelatihan komputer merupakan solusi permasalahan Mitra yakni dengan pemberian pelatihan Microsoft Point dan Pelatihan Internet:

1. Pelatihan Microsoft Power Point salah satu pelatihan yang dapat meningkatkan kompetensi Guru dalam pembuatan Materi pembelajaran menjadi lebih menarik, inovatif, dan lebih variatif bertujuan agar penyampaian Materi pembelajaran kepada Peserta Didik dapat terserap dengan baik karena menjadi nilai tambah dalam tampilan pemberian materi lebih banyak pilihan sehingga akan menambah keterampilan Guru dalam mengelolah komputer untuk menghadapi tantangan Kurikulum K-13. Manfaat bagi Peserta Didik akan bertambahan pengetahuan dan lebih bersemangat dalam menerima Materi Pembelajaran yang di sampaikan oleh Guru SMPN 20 Palembang.

2. Pelatihan Internet untuk Guru SMPN 20 Palembang akan membantu Guru dalam penambahan informasi, pengetahuan, serta pembaharuan dalam materi pembelajaran yang akan disampaikan ke Peserta Didik. Pelatihan Internet menjadikan Guru lebih luas jangkauan wawasan dan menambah keterampilan Guru dalam menghadapi perkembangan teknologi yang semakin pesat maju saat ini. Pelatihan ini di harapkan dapat memberi solusi terhadap Mitra. Pelatihan ini dapat meningkatkan kompetensi Guru sehingga Guru tersebut akan memiliki kualitas dan kuantitas yang baik sehingga dapat meningkatkan Mutu pendidikan di sekolah SMPN 20 Palembang dan dapat meluluskan Peserta Didik yang berkualitas dan memiliki daya saing yang baik.

\subsection{Kesepakatan dengan Pihak Sekolah}

Kesepakatan dengan Pihak Sekolah mengenai waktu dan tempat pelaksanaan kegiatan PkM tersebut. Pihak sekolah menginformasikan kepada seluruh Guru SMPN 20 Palembang untuk mengikuti 
pelatihan Microsoft Power Point dan Pelatihan Internet. Pelatihan tersebut dapat diikuti seluruh Guru SMPN 20 Palembang juga diikuti perwakilan Sekolah yang berada di dekat SMPN 20 Palembang. Kegiatan PkM tersebut dilaksanakan selama 2 hari dari tanggal 8 sampai dengan 9 Mei 2017

\subsection{Persiapan Pelaksanaan}

Persiapan pelaksanaan yang dilakukan dalam kegiatan PkM dengan melakukan survey ke Sekolah SMPN 20 Palembang selanjutnya melakukan wawancara dengan pihak sekolah yakni kepala sekolah dan Guru SMPN 20 Palembang bertujuan untuk memberikan solusi atas permasalahan Mitra. Kemudian melakukan diskusi Menetapkan hari, tanggal kegiatan, tempat serta peralatan yang perlu dipersiapkan untuk pelaksanaan kegiatan pelatihan tersebut, seperti penyediaan ruang pelatihan untuk kapasitas 50 orang yang terdiri Guru SMPN 20 Palembang dan perwakilan guru berasal dari sekitar sekolah SMPN 20 Palembang dan kelengkapan lainnya seperti infocus, printer, spaker aktif dll. Kegiatan pengabdian dilakukan di Aula Pertemuan SMPN 20 Palembang diwajibkan bagi Guru untuk membawa laptop masing-masing. Mengajukan proposal kepada Lembaga Penelitian dan Pengabdian kepada Masyarakat, Kerjasama, dan Pengembangan Bisnis (LP2MKPB) Universitas Indo Global Mandiri (IGM) untuk melaksanakan kegiatan PkM. Setelah itu mempersiapkan materi pelatihan dalam bentuk modul yang akan dibagikan kepada para Guru dan peserta pelatihan. Setelah persiapan selesai, ditetapkan waktu kegiatan pada tanggal 8 dan 9 Mei 2017 di SMPN 20 Palembang.

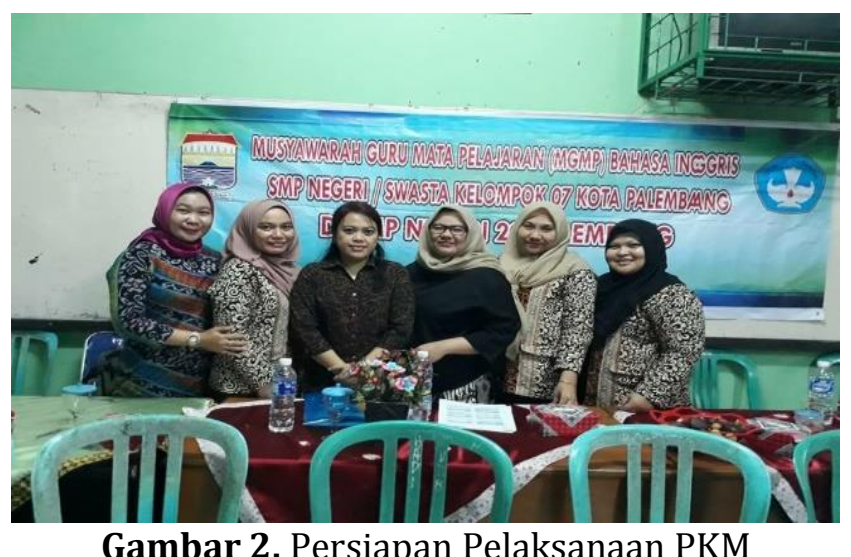

\subsection{Pelaksanaan Pengabdian}

Pelaksanan PkM dimulai dari Pelatihan Microsoft Power Point dan Pelatihan Internet untuk Guru untuk menghadapi Kurikulum K-13, persiapan laporan, materi yang akan disampaikan Microsoft Power Point dan Internet untuk Guru SMPN 20 Palembang. Pelaksanaan pertama dimulai dengan pemberian kata sambutan dari kepala sekolah SMPN 20 Palembang selaku pihak penyelenggara dilanjutkan pembahasan materi untuk Guru yang dibagi 2 (dua) materi pembahasan yakni materi Microsoft Power Point dan materi Internet dan diakhiri dengan penutup.

Materi yang disampaikan pertama adalah pelatihan Microsoft Power Point. Materi ini menjelaskan tentang cara membuat presentasi penyampaian materi pembelajaran yang menarik, inovatif dan variatif sehingga Peserta didik tidak bosan dalam menerima materi pembelajaran yang disampaikan oleh Guru. Materi kedua adalah Internet. Internet adalah sebuah wadah dalam pencarian informasi mengenai pembaharuan dalam isi materi pembelajaran juga tambahan pengetahuan bagi Guru dalam mengaplikasikan teknologi. Pelatihan Internet dapat membantu Guru SMPN 20 Palembang dalam mengelola informasi, informasi yang di dapat lebih up to date dan lengkap membantu Guru dalam pembaharuan dalam membuat materi pembelajaran sehingga peningkatan kompetensi Guru akan semakin meningkat. Guru akan lebih berkualitas dan dapat meningkatkan Mutu Sekolah SMPN 20 Palembang. 


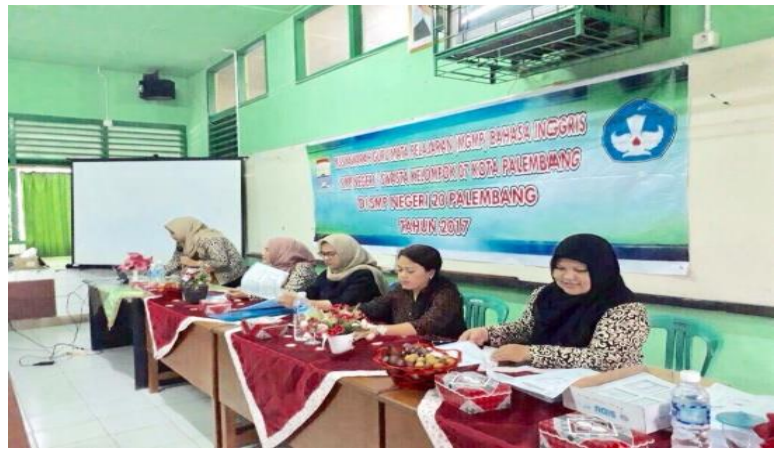

Gambar 3. Pelaksanaan Pemberian Materi

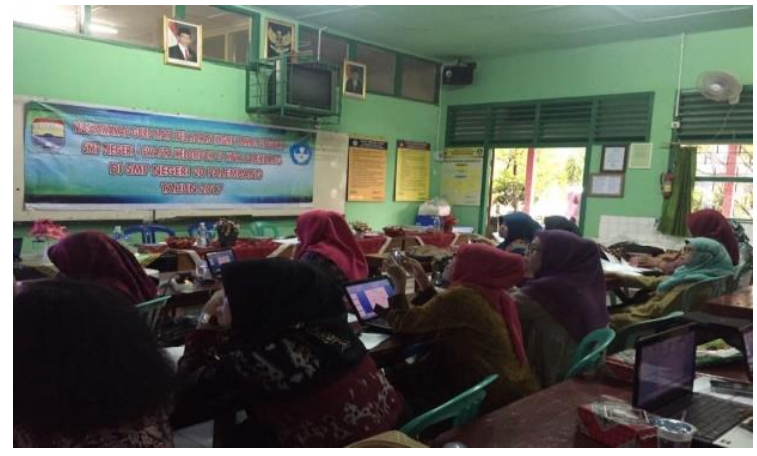

Gambar 4. Pelatihan Untuk Guru SMPN 20

\section{HASIL DAN PEMBAHASAN}

Pelatihan Microsoft Power Point dan pelatihan Internet akan memberi manfaat bagi Guru SMPN 20 Palembang, dalam peningkatan kompetensi Guru untuk menghadapi kurikulum K-13. Pemanfaatan komputer dalam meningkatkan keterampilan Guru dalam mengoperasi Komputer dan keterampilan di bidang komputer. Pelatihan ini dapat menambah kualitas dan kuantitas Guru dan dapat meningkatkan mutu pendidikan SMPN 20 Palembang. Pelatihan Microsoft Power Point bertujuan agar Guru dalam presentasi penyampaian materi lebih menarik, inovatif, dan bervariatif sehingga Peserta Didik dapat menerimanya dengan lebih semangat secara otomatis dapat menyerap pelajaran lebih mudah dan cepat, karena di dalam program Microsoft Power Point memiliki ikon-ikon yang dapat membantu Guru dalam membuat materi pembelajaran yang berbeda-beda di tiap pertemuan, sehingga presentasi penyampaian materi pembelajaran tidak membosankan. Ikon-ikon dalam Microsoft Power point yakni file, Home, Insert, Design, transitions, Animations, Slide Show, Review, View.

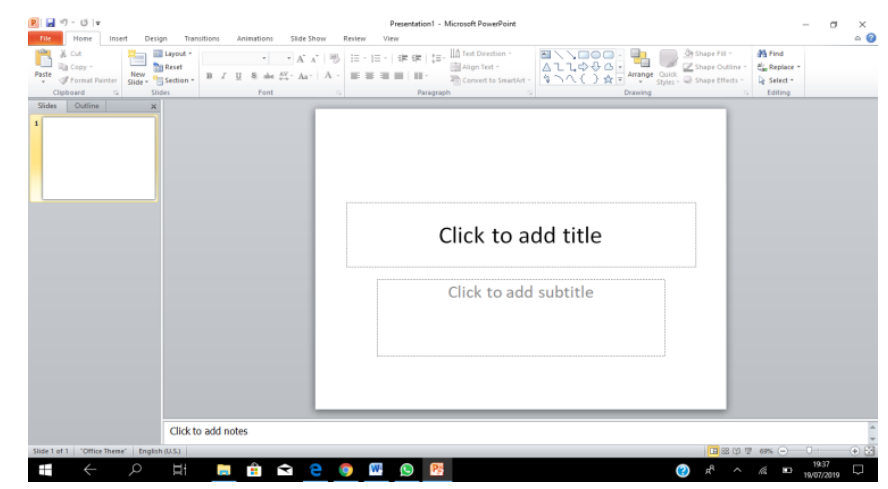

Gambar 5. Tampilan Microsoft Power Point

Untuk memberikan tampilan menarik dapat diambil dari Menu Design, di menu ini terdapat banyak banyak pilihan tampilan yang akan di jadikan acuan untuk peserta dalam membuat tampilan yang menarik.

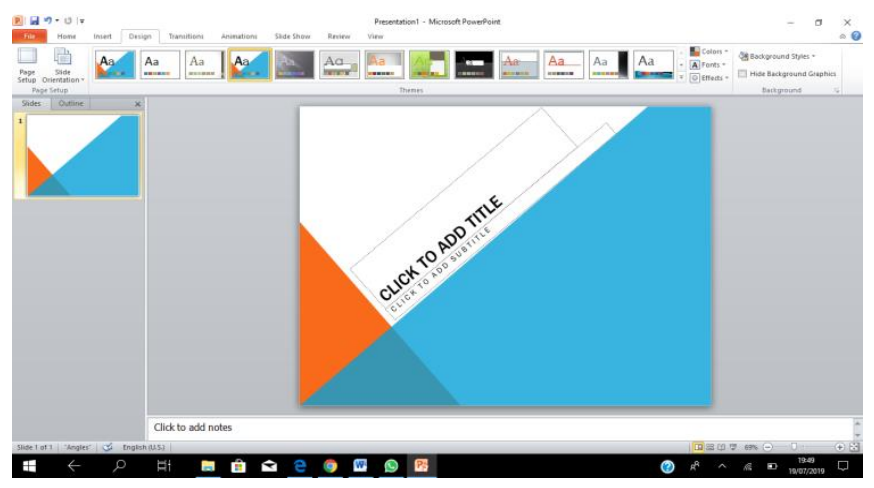

Gambar 6. Menu Desain 
Penambahan animasi di Microsoft Power Point adalah salah satu poin tambahan untuk menjadikan tampilan lebih inovatif dari menu Animation. Menu ini terdiri dari berbagai pilihan animasi yang dapat menampilkan berbagai macam animasi tulisan yang dapat di padukan dengan bantuan video, suara maupun gambar sehingga gambar juga tulisan dapat bergerak sesuai dengan ikon yang kita pilih.

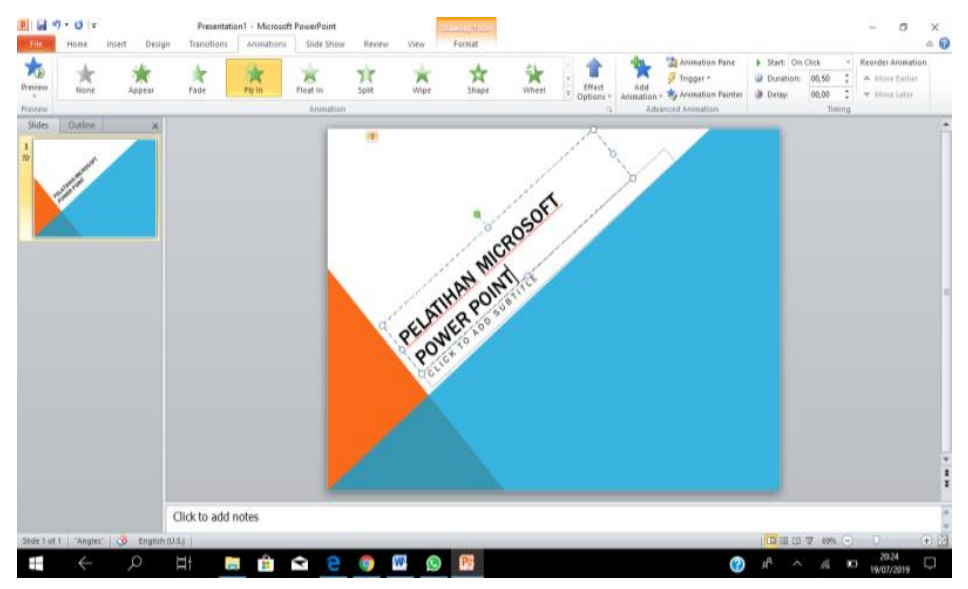

Gambar 7. Menu Animation

Pelatihan Internet yang di berikan juga memberikan banyak manfaat bagi Guru. Internet merupakan wadah dalam mendapatkan banyak informasi. (Said, 2015). Guru dapat mengelolah Internet di harapkan dapat memberikan nilai tambah bagi Guru tersebut, karena dengan Internet Guru dapat memperbaharui materi pembelajaran salah satunya melalui google search juga dapat menambah wawasan dan pengetahuan Guru, membantu menyelesaikan permasalahan atau solusi permasalahan yang di hadapi oleh Guru, Guru juga dapat membuat Game untuk materi pembelajaran agar Peserta Didik tidak bosan menerima pembelajaran karena diselingi dengan permainan Game. Pelatihan Internet memberikan manfaat yang banyak bagi Guru sehingga Guru perlu diadakan pelatihan tersebut.

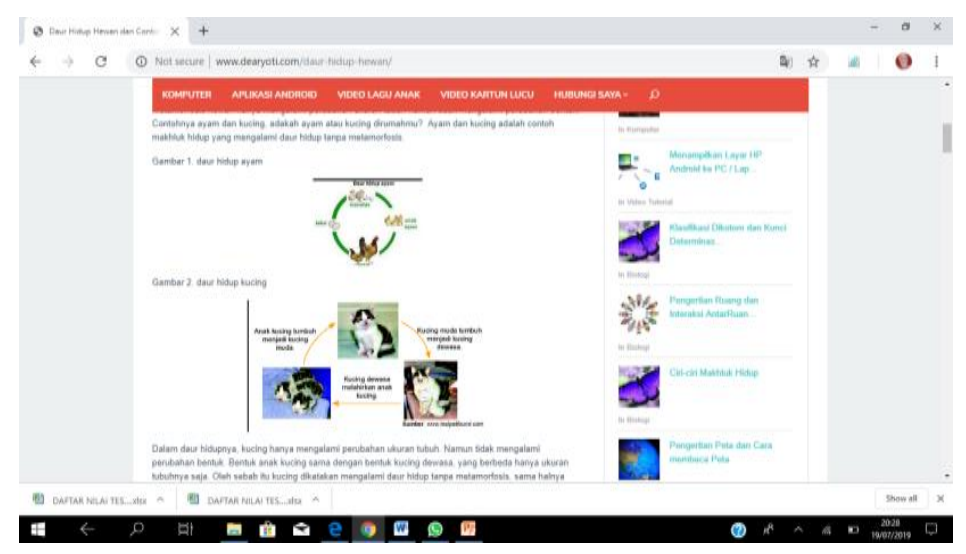

Gambar 8. Menu Animation

\section{KESIMPULAN}

Dari kegiatan PkM yang telah dilakukan, maka dapat disimpulkan beberapa hal, yaitu

1. Pelatihan ini dapat membantu Guru SMPN 20 dalam menghadapi kurikulum K-13;

2. Hasil dari kegiatan PkM ini agar membantu Guru SMPN 20 dalam mengoperasikan Komputer dan Membuat suasana pembelajaran lebih kreatif dan konduksif.

3. Kegiatan ini mendapat sambutan yang baik dari pihak sekolah dan Guru SMPN 20 Palembang

4. Kegiatan ini dapat meningkatkan kompetensi Guru dalam membuat presentasi penyampaian materi pembelajaran melalui pelatihan Microsoft Power Point dan menambah wawasan dan pengetahuan sehingga menghasilkan siswa yang berinovatif. 


\section{UCAPAN TERIMA KASIH}

Ucapan terimakasih diberikan kepada Universitas Indo Global Mandiri selaku pelindung dalam kegiatan ini. Kepala sekolah, Guru di SMPN 20 Palembang yang menjadi peserta pada kegiatan pelatihan ini.

\section{DAFTAR PUSTAKA}

Heryati, A., \& Afriyani, F. 2017. Pelatihan Pembukuan Dan Manajemen Koperasi Bagi Pengurus Koperasi Smpn 26 Kota Palembang. 1(1), 41-45.

Pratiwi, H. I. 2018. Pelatihan Microsoft Office Selatan. 8-13.

Said, H. 2015. Penggunaan Internet Sebagai Media Pembelajaran Pada Mahasiswa Iain Palu. HUNAFA: Jurnal Studia Islamika, 12(1), 95-119. Retrieved from http://www.jurnalhunafa.org/index.php/hunafa/article/view/383

Suharmanto, A. dan S. 2017. Pemanfaatan Internet Sebagai Media Dalam Pembelajaran Pendidikan Pancasila Dan Kewarganegaraan Di Sma Negeri 1 Sleman. Jurnal Pendidikan Kewarganegaraan Dan Hukum, (5), 24-41. 